\title{
Two New Metabolites from Basidiomycete Sparassis crispa
}

\author{
Meng-Yuan Jiang ${ }^{\mathrm{a}, \mathrm{b}}$, Ling Zhang ${ }^{\mathrm{a}, \mathrm{b}}$, Ze-Jun Dong ${ }^{\mathrm{a}}$, and Ji-Kai Liu ${ }^{\mathrm{a}}$ \\ a State Key Laboratory of Phytochemistry and Plant Resources in West China, Kunming Institute \\ of Botany, Chinese Academy of Sciences, Kunming 650204, P. R. China \\ b Graduate University of the Chinese Academy of Sciences, Beijing 100049, P. R. China \\ Reprint requests to Prof. Dr. Ji-Kai Liu. Fax: +86-871-5150227. E-mail: jkliu@mail.kib.ac.cn
}

Z. Naturforsch. 2009, 64b, 1087 - 1089; received May 15, 2009

\begin{abstract}
Two new metabolites, named crispacolide (1) and 3-acetyl-4-hydroxymethyl-tetrahydrofuran (2), were isolated from the fruiting bodies of basidiomycete Sparassis crispa (Wulf.) Fr. The structures and stereochemistry were established on the basis of spectroscopic means.
\end{abstract}

Key words: Crispacolide, 3-Acetyl-4-hydroxymethyl-tetrahydrofuran, Sparassis crispa, Basidiomycete

\section{Introduction}

The fungus Sparassis crispa (Wulf.) Fr. (cauliflower mushroom), which belongs to the family of sparassidaceae, is a culinary-medicinal mushroom found through the temperate regions of Europe, Asia and North America. The fruiting bodies of S. crispa have been reported to exhibit an excellent effect for curing human diseases such as gastric ulcer, oesophageal cancer, hypertension, and diabetes in China $[1-3]$. There are some reports on the isolation of bioactive $\beta$-glucan $[2,4-11]$, phenyl derivatives [12, 13], chalcones [14], and sesquiterpenenoids [15]. As a part of our search for naturally occurring bioactive metabolites from higher fungi in China [16 - 18], we have carried out the chemical investigation on the fruiting bodies of S. crispa and isolated two new metabolites, crispacolide (1) and 3acetyl-4-hydroxymethyl-tetrahydrofuran (2). This paper describes the isolation and the structure elucidation of these two new compounds.

\section{Result and Discussion}

Compound 1 was obtained as a colorless oil. Its molecular formula was established as $\mathrm{C}_{9} \mathrm{H}_{12} \mathrm{O}_{4}$ on the basis of positive ESIMS, ${ }^{13} \mathrm{C}$ NMR and DEPT spectra and further confirmed by HRESIMS at $m / z=207.0635$ (calcd. 207.0633 for $\mathrm{C}_{9} \mathrm{H}_{12} \mathrm{O}_{4} \mathrm{Na}$ ). The IR spectrum showed the absorption of a carbonyl group at 1748 $\mathrm{cm}^{-1}$. The ${ }^{13} \mathrm{C}$ NMR and DEPT spectra (Table 1) revealed nine carbon resonances for one carbonyl at $\delta=$ 169.6 (C-6), one terminal double bond at $\delta=145.7$
Table 1. NMR spectroscopic data $\left(\mathrm{CDCl}_{3}\right)$ for compounds $\mathbf{1}$ and 2.

\begin{tabular}{|c|c|c|c|c|}
\hline & & 1 & & 2 \\
\hline & $\delta_{\mathrm{C}}$ & $\delta_{\mathrm{H}}$ (mult., $J$ in $\mathrm{Hz}$ ) & $\delta_{\mathrm{C}}$ & $\delta_{\mathrm{H}}$ (mult., $J$ in $\mathrm{Hz}$ ) \\
\hline 2 & $70.9, \mathrm{t}$ & $4.43, \mathrm{~d}(2.0)$ & $69.6, \mathrm{t}$ & $4.05, \mathrm{dd}(8.8,8.3)$ \\
\hline & & & & $3.87, \mathrm{dd}(8.8,6.8)$ \\
\hline 3 & $145.7, \mathrm{~s}$ & & $55.3, \mathrm{~d}$ & 3.06, ddd $(8.3,6.8,6.8)$ \\
\hline $3 a$ & $48.5, \mathrm{~d}$ & $3.01, \mathrm{~m}$ & & \\
\hline 4 & $68.0, \mathrm{t}$ & $\begin{array}{l}4.39, \mathrm{dd}(11.8,5.0) \\
4.19, \mathrm{dd}(11.8,6.0)\end{array}$ & $44.6, \mathrm{~d}$ & $2.69, \mathrm{~m}$ \\
\hline 5 & & & $70.7, \mathrm{t}$ & $3.91, \mathrm{dd}(8.8,7.8)$ \\
\hline & & & & $3.62, \mathrm{dd}(8.8,5.9)$ \\
\hline 6 & $169.6, \mathrm{~s}$ & & 207.9, s & \\
\hline 7 & $37.9, \mathrm{t}$ & $2.99, \mathrm{~d}(14.8)$ & $29.3, \mathrm{q}$ & $2.22, \mathrm{~s}$ \\
\hline & & $2.89, \mathrm{~d}(14.8)$ & & \\
\hline $7 a$ & $107.5, \mathrm{~s}$ & & & \\
\hline 8 & $107.6, \mathrm{t}$ & $5.17, \mathrm{~d}(2.0)$ & $64.0, \mathrm{t}$ & 3.68 , dd $(10.8,6.4)$ \\
\hline & & $5.13, \mathrm{~d}(2.0)$ & & 3.60, dd $(10.8,5.9)$ \\
\hline $\mathrm{OMe}$ & $48.9, \mathrm{q}$ & $3.31, \mathrm{~s}$ & & \\
\hline
\end{tabular}
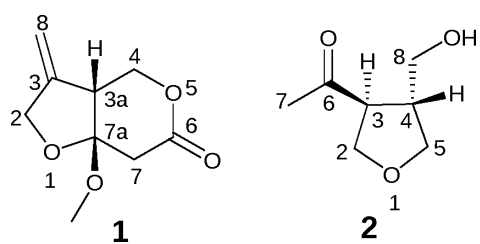

Fig. 1. Structures of 1 and 2.

(C-3) and $107.6(\mathrm{C}-8)$, three methylenes at $\delta=70.9$ (C-2), 68.0 (C-4) and 37.9 (C-7), one methine at $\delta=$ $48.5(\mathrm{C}-3 \mathrm{a})$, one oxymethyl at $\delta=48.9\left(\mathrm{C}-\mathrm{OCH}_{3}\right)$, and a quaternary carbon at $\delta=107.5$ (C-7a). Signals for one methine, four methylenes, and one oxymethyl group were observed in the ${ }^{1} \mathrm{H}$ NMR spectrum of $\mathbf{1}$ (Table 1). Its HMBC spectrum (Fig. 2) exhibited the following key correlations: from $\mathrm{H}-2$ to $\mathrm{C}-3, \mathrm{C}-3 \mathrm{a}$ and 
C-8, from $\mathrm{H}-4$ to $\mathrm{C}-3, \mathrm{C}-6$ and $\mathrm{C}-7 \mathrm{a}$, from $\mathrm{H}-7$ to C-3a, $\mathrm{C}-6$ and $\mathrm{C}-7 \mathrm{a}$, and from $\mathrm{OCH}_{3}$ to $\mathrm{C}-7 \mathrm{a}$. The relative configuration of $\mathbf{1}$ was determined by a ROESY spectrum. The ROESY cross peaks of $\mathrm{H}-3 \mathrm{a} / \mathrm{OCH}_{3}$ indicated that $\mathrm{H}-3 \mathrm{a}$ and the oxymethyl group are on the same side. Therefore, the structure of $\mathbf{1}$ was assigned as shown in Fig. 1, and named as crispacolide. Compound $\mathbf{1}$ is a methyl ketal. It cannot be excluded that it was formed during the extraction and isolation procedures (see Experimental Section below) from the hemiketal which likewise would be a new natural product. Surprisingly, compound $\mathbf{1}$ is optically inactive. This also may point at the possible cyclization of an optically inactive precursor during the extraction procedure.

Compound 2 was also obtained as a colorless oil with a molecular formula of $\mathrm{C}_{7} \mathrm{H}_{12} \mathrm{O}_{3}$ assigned by HRESIMS $(\mathrm{m} / \mathrm{z}=167.0689$; calcd. 167.0684 for $\mathrm{C}_{7} \mathrm{H}_{12} \mathrm{O}_{3} \mathrm{Na}$ ). The IR spectrum showed absorptions at 3445 and $1709 \mathrm{~cm}^{-1}$, revealing the presence of hydroxyl and carbonyl groups. The ${ }^{13} \mathrm{C}$ NMR and DEPT spectra displayed seven signals, including a carbonyl group $[\delta=207.9(\mathrm{C}-6)]$, two methines $[\delta=55.3$ (C-3), 44.6 (C-4)], three methylenes [ $\delta=70.7$ (C-5), 69.6 (C-2), $64.0(\mathrm{C}-8)]$, and a methyl group [ $\delta=29.3$ (C-7)]. The ${ }^{1} \mathrm{H}$ NMR spectrum exhibited resonances at $\delta=2.22(3 \mathrm{H}, \mathrm{s}, \mathrm{H}-7)$ for a methyl, $\delta=2.69(1 \mathrm{H}$, $\mathrm{m}, \mathrm{H}-4)$ and $3.06(1 \mathrm{H}$, ddd, $J=8.3,6.8,6.8 \mathrm{~Hz}, \mathrm{H}-3)$ for two methines, and $\delta=3.60-4.05(6 \mathrm{H})$ for three methylenes. Interpretation of the ${ }^{1} \mathrm{H}-{ }^{1} \mathrm{H}$ COSY and HSQC spectra provided evidence for a partial structure $\mathrm{CH}_{2}-\mathrm{CH}-\mathrm{CH}\left(\mathrm{CH}_{2}\right)-\mathrm{CH}_{2}$. The $\mathrm{HMBC}$ correlations of $\mathrm{H}-2$ with $\mathrm{C}-4, \mathrm{C}-5$ and $\mathrm{C}-6, \mathrm{H}-3$ with $\mathrm{C}-5, \mathrm{C}-7$ and $\mathrm{C}-8, \mathrm{H}-4$ with $\mathrm{C}-2$ and $\mathrm{C}-6, \mathrm{H}-7$ with $\mathrm{C}-3$ and $\mathrm{C}-6$ confirmed the presence of the functional groups noted above and allowed the assignment of the gross structure. The relative configuration of $\mathrm{H}-3, \mathrm{H}-4$-trans was deduced from the ROESY correlations of $\mathrm{H}-3 /$ $\mathrm{H}-8 \mathrm{a}$, while no ROESY correlation of $\mathrm{H}-3 / \mathrm{H}-4$ was observed. Accordingly, the structure of $\mathbf{2}$ was elucidated as shown in Fig. 1.

\section{Experimental Section}

\section{General experimental procedures}

Optical rotations were measured on a Horiba SEPA-300 polarimeter. IR spectra were obtained using a Bruker Tensor 27 FT IR spectrometer with $\mathrm{KBr}$ pellets. NMR spectra were acquired with Bruker DRX-500 and AV-400 instruments at r. t. Mass spectra were recorded with a VG Autospec-3000 spectrometer and an API QSTAR Pulsar i spectrometer. Silica gel (200-300 mesh, Qingdao Marine Chemical Inc.,

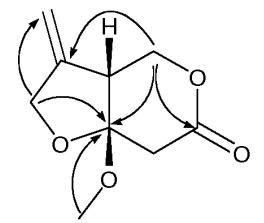

1

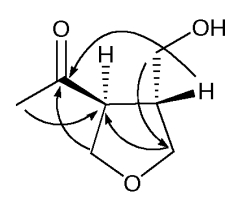

2
Fig. 2. The key HMBC correlations of compounds $\mathbf{1}$ and $\mathbf{2}$.

China) and Sephadex LH-20 (Amersham Biosciences, Sweden) were used for column chromatography.

\section{Fungal material}

The fungus S. crispa was collected at Gaoligong Mountains, Yunnan Province, People's Republic of China, in July 2007, and identified by Prof. Mu Zang, Kunming Institute of Botany. A voucher specimen (HFG 07058) was deposited at the Herbarium of the Kunming Institute of Botany, Chinese Academy of Sciences.

\section{Extraction and isolation}

The fresh fruiting bodies of $S$. crispa $(5.0 \mathrm{~kg})$ were extracted with $95 \% \mathrm{EtOH}(10 \mathrm{~L})$ at r. t. to obtain $285 \mathrm{~g}$ of crude extract, which was submitted to silica gel column chromatography $(\mathrm{CC})$, eluting with a $\mathrm{CHCl}_{3}-\mathrm{MeOH}$ gradient, to afford fractions A-D. Fraction B was subjected to repeated silica gel and Sephadex LH-20 CC to afford compounds $1(5.0 \mathrm{mg})$ and $2(9.0 \mathrm{mg})$.

\section{Crispacolide (1)}

Colorless oil, $[\alpha]_{\mathrm{D}}^{26}=0.00\left(c=0.15, \mathrm{CHCl}_{3}\right) .-\mathrm{IR}$ $(\mathrm{KBr}): v=3471,2998,2916,2862,1748,1673,1468$, 1426, 1387, 1322, 1284, $1184 \mathrm{~cm}^{-1}$. - NMR $\left(\mathrm{CDCl}_{3}, 400\right.$ $\mathrm{MHz})$ see Table 1. - MS ((+)-ESI): $m / z=185[\mathrm{M}+\mathrm{H}]^{+}$, $207[\mathrm{M}+\mathrm{Na}]^{+} .-\mathrm{HRMS}((+)-\mathrm{ESI}): m / z=207.0635$ (calcd. 207.0633 for $\left.\mathrm{C}_{9} \mathrm{H}_{12} \mathrm{O}_{4} \mathrm{Na},[\mathrm{M}+\mathrm{Na}]^{+}\right)$.

\section{3-Acetyl-4-hydroxymethyl-tetrahydrofuran (2)}

Colorless oil, $[\alpha]_{\mathrm{D}}^{25}=+35.1\left(c=0.65, \mathrm{CHCl}_{3}\right) .-\mathrm{IR}$ (KBr): $v=3445,2938,2875,1709,1478,1362,1176,1068$, $924 \mathrm{~cm}^{-1}$. - NMR $\left(\mathrm{CDCl}_{3}, 500 \mathrm{MHz}\right)$ see Table 1. - MS $(\mathrm{EI}, 70 \mathrm{eV}): \mathrm{m} / z(\%)=143\left([\mathrm{M}-\mathrm{H}]^{+}, 5\right), 129\left([\mathrm{M}-\mathrm{Me}]^{+}\right.$, 25), 113 (100). - HRMS ((+)-ESI): $m / z=167.0689$ (calcd. 167.0684 for $\left.\mathrm{C}_{7} \mathrm{H}_{12} \mathrm{O}_{3} \mathrm{Na},[\mathrm{M}+\mathrm{Na}]^{+}\right)$.

\section{Acknowledgement}

This project was supported by the National Basic Research Program of China (973 Program, 2009CB522300), the National Natural Science Foundation of China (308301 13), and the Chinese Academy of Sciences (KSCX1-YW-R24; KSCX2-YW-G-025). 
[1] X. L. Mao, Economic macrofungi of Tibet, Beijing Science and Technology Press, Beijing, 1993, pp. $387-$ 388.

[2] T. Harada, H. Kawaminami, N. N. Miura, Y. Adachi, M. Nakajima, T. Yadomae, N. Ohno, Int. J. Med. Mushr. 2006, 8, 231-244.

[3] M. Y. Kim, I. M. Chung, S. J. Lee, J. K. Ahn, E. H. Kim, M. J. Kim, S. L. Kim, H. I. Moon, H. M. Ro, E. Y. Kang, S. H. Seo, H. K. Song, Food Chem. 2009, 113, $386-393$.

[4] N. Ohno, N. N. Miura, M. Nakajima, T. Yadomae, Biol. Pharm. Bull. 2000, 23, 866-872.

[5] K. Yamamoto, T. Kimura, A. Sugitachi, N. Matsuura, Biol. Pharm. Bull. 2009, 32, 259-263.

[6] R. Tada, T. Harada, N. Nagi-Miura, Y. Adachi, M. Nakajima, T. Yadomae, N. Ohno, Carbohydr. Res. 2007, 342, 2611-2618

[7] H. G. Park, Y. Y. Shim, S. O. Choi, W. M. Park, J. Agric. Food Chem. 2009, 57, 2147-2154.

[8] N. Ohno, S. Nameda, T. Harada, N. N. Miura, Y. Adachi, M. Nakajima, K. Yoshida, H. Yoshida, T. Yadomae, Int. J. Med. Mushr. 2003, 5, 359-368.

[9] N. Ohno, T. Harada, S. Masuzawa, N. N. Miura, Y. Ad- achi, M. Nakajima, T. Yadomae, Int. J. Med. Mushr. 2002, 4, 13-26.

[10] T. Harada, N. N. Miura, Y. Adachi, M. Nakajima, T. Yadomae, N. Ohno, J. Interfer. Cytok. Res. 2002, 22, $1227-1239$.

[11] T. Harada, N. Miura, Y. Adachi, M. Nakajima, T. Yadomae, N. Ohno, Biol. Pharm. Bull. 2002, 25, 931 - 939.

[12] S. Woodward, H. Y. Sultan, D. K. Barrett, R. B. Pearce, J. Gen. Microbiol. 1993, 139, $153-159$.

[13] H. Kawagishi, K. Hayashi, S. Tokuyama, N. Hashimoto, T. Kimura, M. Dombo, Biosci. Biotechnol. Biochem. 2007, 71, 1804-1806.

[14] S. Kodani, K. Hayashi, S. Tokuyama, M. Hashimoto, T. Kimura, M. Dombo, H. Kawagishi, Int. J. Med. Mushr. 2008, 10, 331-336.

[15] S. Kodani, K. Hayashi, M. Hashimoto, T. Kimura, M. Dombo, H. Kawagishi, Biosci. Biotechnol. Biochem. 2009, 73, 228-229.

[16] J. K. Liu, Chem. Rev. 2005, 105, 2723 - 2744.

[17] J. K. Liu, Chem. Rev. 2006, 106, 2209-2223.

[18] D. Z. Liu, F. Wang, T. G. Liao, J. G. Tang, W. Steglich, H. J. Zhu, J. K. Liu, Org. Lett. 2006, 8, 5749-5752. 